\title{
Analysis of Cemex’s Strategies as Determinants for Market Power
}

\section{Hernández JGV*}

Cinthia Zuleima Pavón Villegas, Centro Universitario de Ciencias Económico Administrativas, Universidad de Guadalajara Periférico Norte 799; Núcleo Universitario Los Belenes; C.P. 45100, Zapopan, Jalisco, México

\begin{abstract}
This article, through a qualitative and quantitative analysis, focuses on strategies that CEMEX has carried out to determine how they influence their dominance index or market power. The qualitative analysis is based on mergers and acquisitions; meanwhile, quantitative analysis is performed by means of calculations Herfindahl Hirschman Index and the Index of Dominance. Currently Cementos Mexicanos is the industry leader in building's materials with global presence as it produces markets and distributes cement in approximately 50 countries, maintaining business relationships with approximately 108 nations. Its main strategies are based on the expansion and acquisition of companies in the cement industry.and distributes cement in approximately 50 countries, maintaining business relationships with approximately 108 nations. Its main strategies are based on the expansion and acquisition of companies in the cement industry.
\end{abstract}

Keywords: Acquisitions; Strategy; Expansion; Market power

JEL: D21, F13, G34

\section{Introduction}

This work has an objective to depart from an analysis of the cement industry, specifically in the production and marketing of cement, for the knowledge of the market structure of the industry and the market power that companies have, leading to have an extensive knowledge the status of CEMEX and its environment. Finally, it is analyzed the strategies implemented by CEMEX to see if they are determining the market power it has today. Mexican Cement, CEMEX is best known as the industry leader in building materials. It has global presence as it produces, markets and distributes cement in about 50 countries and has relationships with approximately 108 nations. Given the history of its growth, its main strategies are based on the expansion and acquisition of companies in the cement industry [1]. Analyses are performed for both strategies as calculations and data shown in this article were obtained from the websites of the companies that make up the cement market and CEMEX. CEMEX strategies implemented in the last 4 years are considered, which will be analyzed qualitatively, based on the theory of $\mathrm{M} \& \mathrm{~A}$, to be determined by the results of the influence of these on the market and their power concentration index. Quantitative analysis was performed with calculations Herfindahl Hirschman Index (HHI) and the Index of Dominance (ID), which will be analyzed [2].

\section{Background of Problem}

CEMEX is founded in 1906 with the Cementos Hidalgo plant in northern México. En 1920 began production and marketing of Cementos Portland Monterrey to meet demand in the Northeast México. As part of its strategy in 1931 Cementos Hidalgo and Cementos Portland Monterrey merge to form Cementos Mexicanos SA. Through its focus to increase its production capacity strategy, in 1966 acquires Cementos Maya plant in Merida and thus meet the demand from southern Mexico through Portland Maya Cement brand and to meet the Huasteca region began production in the Valles plant. In 1976 acquires Cementos Guadalajara, whose participation was $10.2 \%$ and covered the Bajio region and the Pacific, getting to be the largest producer of cement in Mexico. In 1986 have achieved one factory more, the Huichapan cement plant which distributed cement in the central region of México.
On the other way in 1986, CEMEX made joint ventures with companies in North America, which were in the same industry, to strengthen their export efforts.

Then, in 1987, CEMEX buy Cementos Anahuac, which controlled $15.7 \%$ of the market operating in the central and Gulf region. In turn, CEMEX implemented its satellite communication system, to have connected all company facilities. In 1989, CEMEX became one of the ten largest cement companies in the world, having acquired Cementos Tolteca, which operated in central and Pacific coast region and controlled $25.8 \%$ of the market being the second largest producer in Mexico. By 1992, CEMEX sought ways to expand its market and its strategy to achieve this was the acquisition of several companies in different countries. The first acquisition performed as part of this strategy was Valenciana and Sanson, which were the largest cement company in Spain, and so was how CEMEX started its international expansion in the European market. Then in 1994 it made three acquisitions. The first was the purchase the company Vencemos in Venezuela, which was one of the largest cement companies in the country, which led her to spread through South America. After acquires Bayano Cement in Panama, making the entrance to Central America. Finally, its third acquisition of the year was Balconies in the United States. In 1995, acquired Cementos Nacionales, in Dominican Republic, settling in the Caribbean region. After purchasing Cementos Diamante and Samper in Colombia, CEMEX becomes the world's third largest cement company in 1996. Starts Operations in Asia, through the acquisition of Rizal Cement in 1997, and APO Cement in 1999, both in Philippines.

*Corresponding author: Hernández JGV, MBA, Ph.D, Cinthia Zuleima Pavón Villegas, Centro Universitario de Ciencias Económico Administrativas, Universidad de Guadalajara Periférico Norte 799; Núcleo Universitario Los Belenes; C.P. 45100, Zapopan, Jalisco, México, Tel: +523337703340 Ext. 25685; E-mail: josevargas@cucea.udg.m, jvargas2006@gmail.com, jgvh0811@yahoo.com

Received September 09, 2014; Accepted February 05, 2015; Published February 15,2015

Citation: Hernández JGV (2015) Analysis of Cemex's Strategies as Determinants for Market Power. J Glob Econ 3: 133. doi:10.4172/2375-4389.1000133

Copyright: (c) 2015 Hernández JGV. This is an open-access article distributed under the terms of the Creative Commons Attribution License, which permits unrestricted use, distribution, and reproduction in any medium, provided the original author and source are credited. 
It was in 1999 when it began operations in the African market after buying Assiut Cement Company, Egypt lead cement producer. After several acquisitions and achieve international expansion, the company was looking to strengthen its presence in the regions where it already was operating. So it begins to step further acquisitions but not based on the expansion, but acquisitions were based on strengthening and make present this brand. That is why in 1999 the acquisition of Cementos hits Pacific, the largest cement producer in Costa Rica, to be even more present in Central America and the Caribbean. In 2000, strengthened its presence in Central America initiating operations in Nicaragua and started operations in 2001 in the Asian market with the acquisition of Saraburi Cement Company in Thailand. In 2002, following the acquisition of Puerto Rican Cement Company, CEMEX consolidated its position in the Caribbean. In 2000, the company launched CEMEX Way, which was an initiative to identify, incorporate and implement the best practices of the organization. This launch that was innovative presented weaknesses, such as debt and mistrust generated by each acquisition made by the manufacturer. That same year [3], CEMEX becomes the largest cement producer in North America, after having acquired Southdown Inc. in the United States. Subsequently, in 2001 CEMEX uses its technology to initiate the online customer service, allowing customers to place orders, purchase products and access services electronically. Since 1993, CEMEX established itself as Neoris, an internal supplier of its own information technology services. By 2003, CEMEX grows with the acquisition of RMC, achieving operations in 20 countries, mainly in Europe; finally in 2007, bought the Australian firm Rinker. Currently the cement industry in Mexico produced aproximadamente 36.2 million tons annually through its 34 installed plants to cover consumption equivalent to 34.6 million tons (CANACEM, 2012) of cement [2]. The industry has an installed capacity of approximately 57.5 million tons. All Cement production is supported by 6 companies competing: CEMEX, which has the largest market share followed by Holcim Apasco, Cruz Azul, Cementos Moctezuma, Cementos Chihuahua and Lafarge Cementos. Given the market power that have some cement companies, this industry is characterized by a highly concentrated market structure in companies with high dominance index.

\section{Defining the Problem}

The main strategy of companies, especially CEMEX is the merger and acquisition of companies and plants as expansion mechanism and in turn as a means to strengthen its presence which generated economies of scale. With this strategy, the company achieved to face competition both internationally and domestically. CEMEX has taken every growth opportunities that have arisen, and all the strategies undertaken are performed under control expenses and costs. As technological advances are made present and the growth of the company requires, it has strengthened technological platforms to have intercommunicated the company globally and in turn to provide better customer service. The strategy of growth and expansion that CEMEX was performing through the reinvestment of generated profits and also funding through issuance of shares and bonds, as from 1976, before CEMEX began with its growth strategy, [3-6] CEMEX already traded on the Mexican Stock Exchange (BMV) and 23 years later, in 1999, it was listed on the Stock Exchange of New York. In 2000, CEMEX Way is launched as an initiative to identify, incorporate and implement the best practices of the organization which had weaknesses as mistrust and debt. Even with this, with all operations of performed growth, cash flow of CEMEX reported a growing trend. With this, the company managed to strengthen financially that allowed it to continue with acquisitions.
Its free cash flow the company took a major part to invest in acquisitions and the rest of the flow is destined to reduce the debt generated by the acquisitions performed. As a result, CEMEX managed to reduce its net debt to EBITDA of 3.2 to 2.7 times by the end of 2003. For that year, increased to 5.3 times its interest coverage and refinanced 2,400 million of debt maturities (Informe Anual, 2003) [7]. This situation is repeated in the following acquisitions. With the implementation of the strategy of expansion and growth, the company showed steady growth which led her to become the world's third largest cement manufacturer and first company which marketed cement worldwide. For the purchase of RMC Corporation in 2005 and Rinker in 2007, CEMEX had to acquire a high debt to the bank, which was possible due to, as it has been mentioned above; CEMEX was supported by the generation of free cash flow. But after the economic crisis of 2008, [5] which started in real estate, significantly decreased sales company which eventually affected the debt at that time it had acquired. In the s67ame year with the global crisis, CEMEX had lost its international position. Another strategy that implemented over time, was the geographical diversification of its assets, leading to new markets the production of cement, concrete and aggregates. Another strategy was vertical integration of its operations, and shares acquired as part of the cement value chain, as companies from drawing raw materials from the mines. These strategies in addition to the others already mentioned, which takes CEMEX to be a competitor renowned worldwide.

\section{Justification}

The analysis focuses on CEMEX because it is the company with the largest market share of Mexican origin, so it is considered important to know its status, and its performance over time, as well as strategies that led to where is, and more importantly, what has it done to overcome a debt that has cost its stability? [6]. It is also important to know how well-developed and well-implemented strategy based on tight control of costs and expenses, such as in the case of acquisitions, can lead to bankruptcy for a company well established and large that it is. And more even when in an environmental analysis regarding the debt acquired with each acquisition, does not includes a possible economic crisis.

\section{Hypothesis}

A growth strategy based on the acquisition and generating debt to a company, in this case CEMEX, must integrate a rigorous control of costs and expenses as well as an analysis of risk and return considering internal aspects of the company and the environment. Also it is considered taking it to the end of an economic crisis, which together can lead to better results than those presented by CEMEX [8].

\section{Conceptual Theoretical Framework}

Peng defines acquisition as "the transfer of control of the assets, operations and management from one firm to another" [9]. There are three types of mergers and acquisitions:

A. Horizontal: When firms competing in the same industry are involved.

\section{B. Vertical: When are involved suppliers and buyers.}

C. Cluster: When firms with unrelated products are involved.

The motives driving these transactions are synergy and administrative arrogance. Analyzing acquisitions that CEMEX has done, it can be seen that its acquisitions in plants and businesses around the world have been horizontal since all these cement companies were acquired from various countries, which had good position in 
the local market. When CEMEX chose Neoris as internal provider on Information Technology, it was a conglomerate acquisition since the purchase was based on technological developments. A previously aforementioned strategy was vertical integration of operations, where he acquired shares as part of the cement value chain, as companies from drawing raw materials from the mines.

According to the theory based on industry, Peng [9] considers risk reduction, which CEMEX not considered in full by not considering a possible crisis. The resource-based theory includes leveraging administrative capacity, and access to complementary resources, what CEMEX made to cover all their resources to pay off the debt acquired after each acquisition

\section{Contextual Frame Work}

The construction industry, based on the 2009 Economic Census, recorded a GDP contribution of 7.2\%. (INEGI, 2009) [5-6]. Based on information provided by the National Chamber of Cement (Canacem, 2012) the annual Grey Cement consumption in 2012 was 34.6 million tons, while the annual production was 36.2 million tons throwing an annual per capita consumption equivalent to $295 \mathrm{~kg}$. Currently this Chamber does not report figures on consumption of 2013, nor disclose what companies like Cementos Fortaleza, Moctezuma, Cruz Azul, etc. In Table 1, it has been recorded that from 2011 to 2012 there was a $0.8 \%$ increase in cement production, as domestic consumption had increased by $0.2 \%$. With the production generated in 2012 , it was possible to meet the demand of consumers, leaving a surplus for the producer of $1.6 \%$, representing an increase of $0.6 \%$ over the previous year's surplus (Table 1). In Mexico there are 6 major cement producing companies that are part of the industry, which in total have some of the 34 plants installed in the country. The following table shows how many plants are owned by each company. With the integrated information in this Table 1 it was designed (Figure 1) conducted to analyze the market share and see which layer contributes more to the production of cement. To analyze how the market is concentrated in this sector, the following information, obtained by INEGI (2009) and calculated with data from the "Total gross output" on economic activity "Manufacture of cement and cement based products in integrated cement plants" as it is where is classified the cement production. With the integrated information in this Table 2 was designed Figure 2 to determine the market power of each stratum, based on gross production and market share [10].

Based on the chart on Figure 1 above, it can be seen that the

\begin{tabular}{|l|c|c|c|c|}
\hline Year & $\begin{array}{c}\text { Production } \\
\text { (In million tons } \\
\text { cement gray.) }\end{array}$ & $\begin{array}{c}\text { National } \\
\text { consumption } \\
\text { (millions tons.) }\end{array}$ & Inhabitants & Inhabitants/kgs \\
\hline 2000 & 31.7 & 29.4 & $99,929,495$ & 294 \\
\hline 2001 & 30 & 27.7 & $101,208,925$ & 273 \\
\hline 2002 & 31.1 & 28.8 & $102,443,471$ & 281 \\
\hline 2003 & 31.9 & 29.6 & $103,636,353$ & 285 \\
\hline 2004 & 33.2 & 30.9 & $104,790,554$ & 295 \\
\hline 2005 & 34.7 & 32.7 & $103,946,866$ & 314 \\
\hline 2006 & 37.9 & 35.9 & $104,874,282$ & 342 \\
\hline 2007 & 38.8 & 36.8 & $105,790,725$ & 347 \\
\hline 2008 & 37.1 & 35.1 & $106,682,512$ & 329 \\
\hline 2009 & 35.1 & 34.4 & $107,550,697$ & 321 \\
\hline 2010 & 34.5 & 33.9 & $112,336,538$ & 301 \\
\hline 2011 & 35.4 & 34.4 & $114,975,406$ & 299 \\
\hline 2012 & 36.2 & 34.6 & $116,901,761$ & 295 \\
\hline
\end{tabular}

Table 1: Production and domestic consumption of cement.

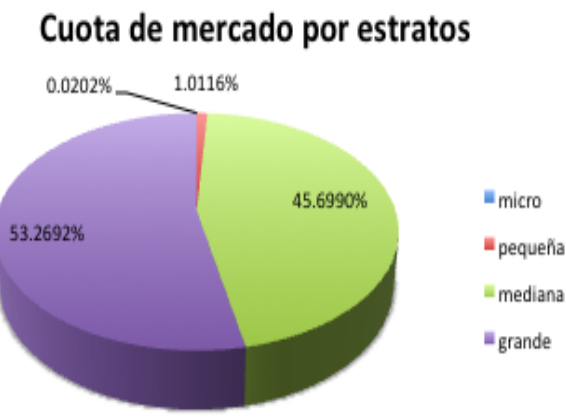

Figure 1: Market share by strata.

\begin{tabular}{|l|c|}
\hline Firm & Number of plants \\
\hline 1. Lafarge Cementos & 2 \\
\hline 2. Grupo Cementos Chihuahua (GCC Cemento) & 3 \\
\hline 3. Cementos Moctezuma & 3 \\
\hline $\begin{array}{l}\text { 4. Cementos y Concretos Nacionales (CYCNA, } \\
\text { Grupo Industrial Cruz Azul) }\end{array}$ & 4 \\
\hline 5. Holcim Apasco & 7 \\
\hline 6. Cementos Mexicanos (CEMEX) & 15 \\
\hline Source Canacem (2012) Total & 34 \\
\hline
\end{tabular}

Table 2: Distribution of installed plants in Mexico.

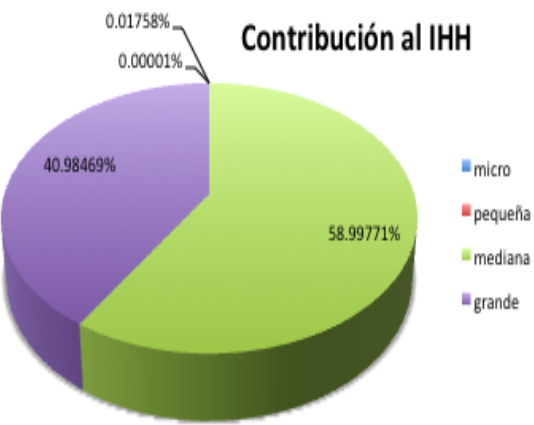

Figure 2: Contribution of Herfindahl Hirschman Index $\mathrm{HHI}$ ).

market share of the cement industry is distributed among medium and large production strata. In 12 large companies is concentrated $53 \%$ of production and 15 medium enterprises $46 \%[5,6]$. From the above calculation, based on gross output, it is shown that midsize companies accumulate $59 \%$ of market concentration, while large account for $41 \%$. The information is shown in Figure 2.

Based on the Herfindahl Hirschman Index (HHI) calculated, it follows that the cement industry tends to perfect competition but, as indicated by the Index of Dominance (ID) it has an oligopolistic structure of a HHI of 2785.97. On the other hand it is considered that is an oligopoly because only 6 companies produce the total market, which leads to a high degree of interdependence, as each company is awaiting the actions performed by their competitors because they will influence the actions and decisions of all other firms involved. With the integrated information of Table 3 was performed (Figure 3), which was to see how support is distributed about market power in companies that today are in the cement industry market. Based on data from 2012 on the market share of 6 companies that currently rests in cement 
Citation: Hernández JGV (2015) Analysis of Cemex's Strategies as Determinants for Market Power. J Glob Econ 3: 133. doi:10.4172/23754389.1000133

Page 4 of 5

\begin{tabular}{|c|c|c|c|c|c|}
\hline Estrata & Economic units & Market share & $\begin{array}{l}\text { Total gross production } \\
\text { (Thousands of pesos) }\end{array}$ & Contribution by strata & Firms strata \\
\hline To t a I & 51 & $100.00 \%$ & $53,696,769$ & $100.00 \%$ & According to INEG| \\
\hline 0 to 2 & 4 & $0.0002 \%$ & 100 & \multirow{3}{*}{$0.02 \%$} & \multirow{3}{*}{ micro } \\
\hline 3 to 5 & & $0.0016 \%$ & 850 & & \\
\hline 6 to 10 & 4 & $0.0184 \%$ & 9,900 & & \\
\hline 11 to 15 & & $0.0121 \%$ & 6,500 & \multirow{4}{*}{$1.01 \%$} & \multirow{4}{*}{ small } \\
\hline 16 to 20 & & $0.0461 \%$ & 24,766 & & \\
\hline 21 to 30 & 6 & $0.3481 \%$ & 186,898 & & \\
\hline 31 to 50 & & $0.6053 \%$ & 325,035 & & \\
\hline 51 to 100 & & $5.5367 \%$ & $2,973,016$ & \multirow{2}{*}{$45.70 \%$} & \multirow{2}{*}{ medium } \\
\hline 101 to 250 & 15 & $40.1623 \%$ & $21,565,850$ & & \\
\hline 251 to 500 & 8 & $25.2447 \%$ & $13,555,576$ & \multirow{3}{*}{$53.27 \%$} & \multirow{3}{*}{ big } \\
\hline 501 to 1000 & 4 & $21.4904 \%$ & $11,539,632$ & & \\
\hline 1001 and more & & $6.5342 \%$ & $3,508,646$ & & \\
\hline
\end{tabular}

Table 3: Market share based on the production of cement per stratum.

Cuota de Mercado

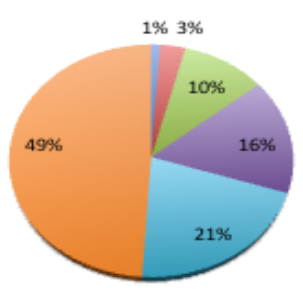

=1. Lafarge Cementos
(Cementos Fortaleza)

2. Grupo Cementos

Chihuahua (GCC

3. Cementos Moctezuma

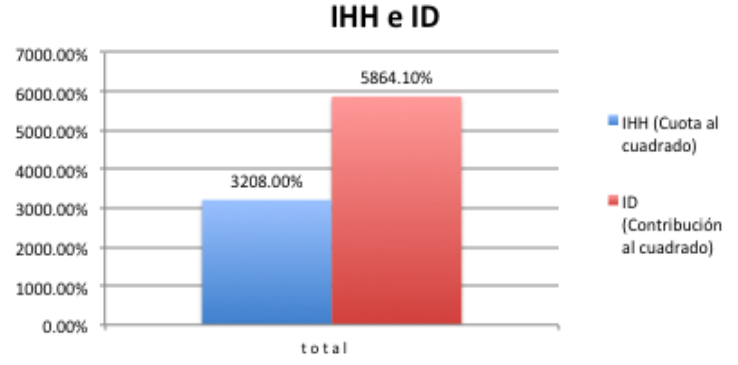

Figure 3: Market share and IHH and ID.

\begin{tabular}{|c|c|c|c|c|}
\hline Estrata & Market share & IHH (Squareshare) & Contribution to IHH & ID (Square contribution) \\
\hline Total & $100.00 \%$ & $2785.979285748 \%$ & $100.00 \%$ & $0.000000001 \%$ \\
\hline 0 to 2 & $0.0002 \%$ & $0.000000035 \%$ & $0.000000090 \%$ & $0.0000000000000000015 \%$ \\
\hline 3 to 5 & $0.0016 \%$ & $0.000002506 \%$ & $0.000012201 \%$ & $0.0000000000000080896 \%$ \\
\hline 6 to 10 & $0.0184 \%$ & $0.000339918 \%$ & $0.000005260 \%$ & $0.0000000001488649289 \%$ \\
\hline 11 to 15 & $0.0121 \%$ & $0.000146531 \%$ & $0.000076355 \%$ & $0.0000000058300877360 \%$ \\
\hline 16 to 20 & $0.0461 \%$ & $0.002127235 \%$ & $0.004348456 \%$ & $0.0000189090727229762 \%$ \\
\hline 21 to 30 & $0.3481 \%$ & $0.121147093 \%$ & $0.013151826 \%$ & $0.0001729705357682000 \%$ \\
\hline 31 to 50 & $0.6053 \%$ & $0.366407157 \%$ & $1.100323278 \%$ & $1.2107113170393300000 \%$ \\
\hline 101 to 100 & $5.5367 \%$ & $30.654778613 \%$ & $57.897387615 \%$ & $22.875034646 \%$ \\
\hline $251-500$ & $40.1623 \%$ & $1613.009225940 \%$ & $16.577144637 \%$ \\
\hline
\end{tabular}

Table 4: IHH and ID strata, based on the national cement production.

production, the following results were obtained (Figure 3 ). In the table above it can be seen how the distribution market for the production of cement in Mexico is. The results of both the IHH and ID confirmed that the cement industry is an oligopoly where CEMEX has a concentration of $49 \%$ of production compared to Lafarge Cementos who is just $1 \%$. As for the important strategies CEMEX has made a couple of years ago, is its strategy to expand its distribution network. According to the magazine Expansion (2012), in Mexico, 60\% of cement demand comes from the segment of self-construction and of this amount approximately $85 \%$ is marketed by bags of cement, the remaining $15 \%$ is sold bulk. From this demand, for CEMEX, consumers engaged in housing construction represent $30 \%$ of this; the sale of cement lumps represents just over $60 \%$ of cement demand which are marketed through its distributors. This growth in the market share of CEMEX is a result of the strategy that the company implemented in order to expand its distribution network and expansion strategy and in turn as a means to make their brand stronger. This strategy consists of opening Construrama stores, which are run by dealers who were already marketing cement or are entering the market with this strategy. The Construrama are shops dedicated to retailing of building materials, aiming to sell a certain amount of cement per month. With that CEMEX has successfully expanded its distribution network to meet the demand of a key market. Through the annual report of the company, CEMEX announced that 6 of every 10 sacks of cement sold in Mexico and Colombia are through Construrama.

\section{Conclusion}

CEMEX has implemented significant strategies for the company 
Citation: Hernández JGV (2015) Analysis of Cemex's Strategies as Determinants for Market Power. J Glob Econ 3: 133. doi:10.4172/23754389.1000133

Page 5 of 5

\begin{tabular}{|c|c|c|c|c|c|c|}
\hline Company & $\begin{array}{l}\text { Number of } \\
\text { plants }\end{array}$ & Market share & $\begin{array}{l}\text { Total production } \\
\text { (millions tons) }\end{array}$ & $\begin{array}{c}\text { IHH } \\
\text { (Square share) }\end{array}$ & $\begin{array}{c}\text { Contribution to } \\
\text { IHH }\end{array}$ & $\begin{array}{c}\text { ID } \\
\text { (Square contribution) }\end{array}$ \\
\hline total & 34.00 & $100 \%$ & 36.2 & $3208.00 \%$ & $100.00 \%$ & $5864.10 \%$ \\
\hline 1. Lafarge Cementos (Cementos Fortaleza) & 2 & $1 \%$ & 0.36 & $1.00 \%$ & $0.03 \%$ & $0.001 \%$ \\
\hline $\begin{array}{l}\text { 2. Grupo Cementos Chihuahua (GCC } \\
\text { Cemento) }\end{array}$ & 3 & $3 \%$ & 1.09 & $9.00 \%$ & $0.28 \%$ & $0.079 \%$ \\
\hline 3. Cementos Moctezuma & 3 & $10 \%$ & 3.62 & $100.00 \%$ & $3.12 \%$ & $9.717 \%$ \\
\hline $\begin{array}{l}\text { 4. Cementos y Concretos Nacionales } \\
\text { (CYCNA, Grupo Cruz Azul) }\end{array}$ & 4 & $16 \%$ & 5.79 & $256.00 \%$ & $7.98 \%$ & $63.681 \%$ \\
\hline 5. Holcim Apasco & 7 & $21 \%$ & 7.60 & $441.00 \%$ & $13.75 \%$ & $188.977 \%$ \\
\hline 6. Cementos Mexicanos (CEMEX) & 15 & $49 \%$ & 17.74 & $2401.00 \%$ & $74.84 \%$ & $5601.645 \%$ \\
\hline
\end{tabular}

Table 5: IHH and ID of the 6 companies producing cement.

but the main error of its acquisition strategy was to risk with debt through recent acquisitions that were made. All strategies which has implemented CEMEX definitely led to position itself as the cement company with greater participation in Mexican industry. The acquisition of Rinker could be the point that affected CEMEX leaving it in a state of financial instability which in turn was pushed by worldwide economic crisis into a huge debt. Imagining that if CEMEX had not acquired the company Rinker, its debt level would have been much less than now it currently has, could have stability with the implementation of appropriate strategies. Currently its strategy of expanding the distribution network covering CEMEX is making much of the market, so the debt versus market power may hold in the market.

\section{Analytical Method}

The methods used for the analysis conducted were qualitative and quantitative. Qualitative analysis was performed with backed arguments primarily on mergers and acquisitions theory, which allowed reaching substantiated analysis. Meanwhile the quantitative analysis was performed with calculations based on data obtained from the sources indicated in each table. The following tables corresponding to graphic information are displayed and described above (Tables 3-5).

\section{References}

1. Babu G, Martinez S (2008) Recent developments in the cement industry: a comparative study between Mexico and India. Portes, Mexican Journal of Studies on the Pacific Rim 2: 165-202.

2. CANACEM (2012) Consumers National Del Cements.

3. CEMEX (2014) Neustra history.

4. Expansión (2012) Slim-Del Vallemake cement business

5. INEGI (2009) Economic census

6. INEGI (2009) Economic Census; Interactive consult of data

7. Informe annual (2003) Annual report of CEMEX,

8. Informe anual (2013) Annual report of CEMEX,

9. Peng M (2010) Global strategy. México, Cengage Learning.

10. Vargas G, Luna A (2012) The role of uncertainty in the crisis of Cemex. Informa Economics 372: 34-50. 